Jurnal Keperawatan Silampari

Volume 3, Nomor 1, Desember 2019

e-ISSN: 2581-1975

p-ISSN: 2597-7482

DOI: https://doi.org/10.31539/jks.v3i1.883

\title{
HUBUNGAN DUKUNGAN KELUARGA, TINGKAT PENDIDIKAN DAN USIA DENGAN KEPATUHAN DALAM PEMBATASAN ASUPAN CAIRAN PADA KLIEN ESRD YANG MENJALANI TERAPI HEMODIALISA
}

\author{
Andri Kusuma Wijaya ${ }^{1}$, Padila $^{2}$ \\ Program Studi Ilmu Keperawatan, Universitas Muhammadiyah Bengkulu ${ }^{1}$ \\ Program Studi Profesi Ners, Universitas Muhammadiyah Bengkulu ${ }^{2}$ \\ andrikwijaya@umb.ac.id ${ }^{1}$
}

\begin{abstract}
ABSTRAK
Penelitian ini bertujuan mengetahui hubungan dukungan keluarga, tingkat pendidikan dan usia dengan kepatuhan klien hemodialisa dalam melakukan pembatasan asupan cairan di Rumah Sakit Umum Daerah Dr M Yunus Bengkulu. Penelitian ini menggunakan rancangan penelitian cross sectional. Hasil analisis terbukti adanya hubungan antara dukungan keluarga dengan nilai ( $p$ value $=0,000)$ terhadap kepatuhan klien hemodialisa dalam melakukan pembatasan asupan cairan, sedangkan variabel tingkat pendidikan ( $p$ value $=0,762$ ) tidak ada hubungan antara kepatuhan klien yang melakukan tindakan hemodialisa dalam melakukan pembatasan asupan cairan, sementara untuk variabel usia ( $p$ value $=0,728$ ) juga tidak ada hubungan antara kepatuhan klien yang mendapatkan tindakan hemodialisa dalam melakukan pembatasan asupan cairan. Simpulan, Dukungan keluarga adalah hal sangat penting yang perlu diperhatikan sebagai salah satu faktor yang dapat menaikan serta meningkatkan kepatuhan dalam melakukan pembatasan asupan cairan klien yang mendapatkan tindakan hemodialisa, sehingga diharapkan dukungan keluarga dapat dimaksimalkan lagi pemberianya untuk menciptakan prilaku yang patuh sehingga mampu membuat klien sadar terhadap pembatasan asupan cairan dengan cara diinformasikan kepada pihak keluarga terutama melalui tatanan klinik hemodialisa yang senantiasa melayani klien End Stage Renal Disease yang mendapatkan tindakan hemodialisa.
\end{abstract}

Kata Kunci: ESRD, IDWG, Kepatuhan

\section{ABSTRACT}

This study aims to determine the relationship of family support, education level and age with hemodialysis client compliance in limiting fluid intake at the Regional Hospital Dr. $M$ Yunus Bengkulu. This study used a cross sectional study design. The results of the analysis proved a relationship between family support and the value ( $p$ value $=0,000$ ) to the client's compliance with hemodialysis in limiting fluid intake, while the variable level of education ( $p$ value $=0.762$ ) there was no relationship between client compliance with hemodialysis in performing restrictions on fluid intake, while for the age variable ( $p$ value $=0.728$ ) there is also no relationship between client compliance with hemodialysis in limiting fluid intake. Conclusion, Family support is a very important thing that needs to be considered as one of the factors that can increase and increase compliance in limiting fluid intake of clients who receive hemodialysis, so that family support is expected to be maximized in giving to create compliant behavior so as 
to make clients aware to limit fluid intake by being informed to the family, especially through the hemodialysis clinical order that always serves End Stage Renal Disease clients who get hemodialysis.

Keywords: ESRD, IDWG, Compliance

\section{PENDAHULUAN}

End Stage Renal Disease (ESRD) adalah gangguan fungsi ginjal yang bersifat progresif dan irreversible, dimana kemampuan tubuh gagal untuk mempertahankan keseimbangan cairan dan elektrolit sehingga menyebabkan uremia (Smeltzer, Bare, 2008). Dampak lain yang bisa terjadi adalah (1) ginjal kehilangan kemampuan untuk mengkonsentrasikan atau mengencerkan urin secara normal, hal ini terjadi karena adanya penahanan cairan dan natrium sehingga meningkatkan resiko terjadinya edema, gagal jantung kongestif dan penyakit hipertensi, (2) terjadinya anemia, hal ini sebagai akibat dari produksi eritropoetin yang tidak adekuat, memendeknya usia sel darah merah, defisiensi nutrisi, dan kecenderungan untuk terjadi perdarahan akibat status uremik pasien, terutama dari saluran gastrointestinal (Padila, 2012).

Data tahun 2000 di Amerika menyatakan insiden end stage renal disease diperkirakan 100 kasus per satu juta penduduk pertahun, dan angka ini meningkat sekitar $8 \%$ setiap tahunnya. Di Malaysia dengan populasi 18 juta, diperkirakan terdapat 1800 kasus baru end stage renal disease pertahunnya. Negara berkembang lainnya insiden ini diperkirakan 40-60 kasus per satu juta penduduk pertahunnya (Sudoyo dkk, 2009).

Berdasarkan data Riskesdas (2013) menunjukkan prevalensi end stage renal disease di Indonesia sebesar 0,2 persen. Prevalensi tertinggi di Sulawesi Tengah sebesar 0,5 persen, diikuti Aceh, Gorontalo, dan Sulawesi Utara masing-masing 0,4 persen. Sementara Nusa Tenggara Timur, Sulawesi Selatan, Lampung, Jawa Barat, Jawa Tengah, Yogyakarta, dan Jawa Timur masing-masing 0,3 persen. Untuk provinsi Bengkulu, Jambi, Sumatera Utara, Sumatera Barat, Banten, Bali, Kalimantan Barat masing-masing 0,2 persen.

Pada klien end stage renal disease penanganan dapat dilakukan dengan berbagai jenis fasilitas layanan yang sesuai dengan keinginan dan kemampuan klien. Menurut data Pernefri (2012) dijelaskan bahwasanya jenis fasilitas layanan yang di berikan oleh renal unit adalah layanan hemodialisa (78\%), transplantasi ginjal (16\%), Continous Ambulatory Peritoneal Dialysis (CAPD) (3\%), Continuous Renal Replacement Therapy (CRRT) (3\%). Jumlah klien baru dan klien aktif yang menjalani terapi hemodialisa terus mengalami peningkatan dari tahun ketahun. Pada tahun 2007 jumlah klien baru 4977 dengan klien aktif sejumlah 1885, tahun 2008 jumlah klien baru 5392 dengan klien aktif sejumlah 1936, tahun 2009 jumlah klien baru 8193 dengan klien aktif sejumlah 4707, tahun 2010 jumlah klien baru 9649 dengan klien aktif sejumlah 5184, tahun 2011 jumlah klien baru 15353 dengan klien aktif sejumlah 6951, tahun 2012 jumlah klien baru 19621 dengan klien aktif sejumlah 9161. Jumlah klien laki-laki setiap tahunya melebihi jumlah klien perempuan.

Klien dengan end stage renal disease yang menjalani terapi hemodialisa dapat mengalami penambahan berat badan diantara dua waktu hemodialisa atau yang dimanifestasikan dengan ketidakpatuhan dalam pembatasan asupan cairan yang disebabkan oleh ketidakmampuan fungsi ekskresi ginjal, karena jumlah nefron yang 
berfungsi semakin menurun, sehingga GFR total menjadi menurun yang menyebabkan terjadinya kelebihan cairan atau edema, kelemahan fisik, pruritus (Blacks, Hawk, 2014).

Untuk mengatasi penambahan berat badan tersebut yang disebabkan oleh asupan cairan yang berlebihan maka dapat dilakukan tindakan pembatasan asupan cairan. Pembatasan asupan cairan mempunyai tujuan untuk mengurangi kelebihan cairan pada periode interdialitik. Kelebihan cairan dapat menyebabkan edema dan hipertensi, hipertropi ventrikuler kiri dan juga berhubungan dengan mortalitas klien (Ifudu et al, 1997 dalam Istanti 2014). Kepatuhan klien terhadap pembatasan asupan cairan merupakan hal yang sangat berperan untuk mencegah terjadinya penambahan berat badan diantara dua waktu hemodialisa.

Menurut penelitian Kugler (2005) tentang ketidakpatuhan klien terhadap diet dan pembatasan asupan cairan pada dewasa yang menjalani terapi hemodialisa didapatkan hasil masih banyak klien yang memiliki ketidakpatuhan terhadap pembatasan asupan cairan sebesar (74,6\%). Sedangkan hasil penelitian Wahyudi, Fitri (2012) menjelaskan ada hubungan kepatuhan diet dengan berat badan sebelum melakukan terapi hemodialisa dimana hubungan tersebut dapat diartikan semakin tinggi kepatuhan maka akan semakin turun berat badan klien sebelum melakukan terapi hemodialisa.

Faktor lain dijelaskan oleh Kamaluddin, Rahayu (2009) bahwa faktor-faktor yang dapat mempengaruhi kepatuhan asupan cairan adalah faktor tingkat pendidikan, pengetahuan klien serta keterlibatan tenaga kesehatan dalam memberikan pelayanan kepada klien yang menjalani terapi hemodialisa. Sedangkan hasil penelitian yang dilakukan oleh Ismail dkk, (2012) dengan subjek pasien gagal ginjal kronik di RSUD Pusat DR. Wahidin Sudirohusodo Makassar menunjukkan bahwa ada hubungan antara tingkat pendidikan dengan kepatuhan diet pada pasien gagal ginjal kronik yang menjalani terapi hemodialisa. Faktor lain yang dapat meningkatkan kepatuhan klien dalam menjalani terapi pengobatan seperti halnya terapi hemodialisa dimana didalamnya termasuk pembatasan asupan cairan adalah keluarga.

Dukungan keluarga merupakan salah satu faktor yang bisa mempengaruhi ketidakpatuhan. Keluarga dapat membantu menghilangkan godaan pada ketidakpatuhan dan keluarga seringkali dapat menjadi kelompok pendukung untuk meningkatkan kepatuhan dalam pembatasan asupan cairan. Dukungan yang diberikan oleh keluarga yaitu berupa dukungan secara instrumental, informasional, emosional dan dukungan berupa pengharapan. Hal lain yang mempengaruhi kepatuhan dalam pembatasan asupan cairan adalah usia. Dimana usia merupakan salah satu faktor yang dapat mempengaruhi perubahan perilaku seseorang, sedangkan dalam kepatuhan usia termasuk dalam salah satu komponen dari faktor klien yang mampu mempengaruhi kepatuhan seseorang dalam membatasi asupan cairan (Sumigar dkk, 2015).

Fenomena yang ditemukan oleh peneliti saat melaksanakan kegiatan supervisi praktek mahasiswa profesi ners stase keperawatan medikal bedah I di ruang Hemodialisa Rumah Umum Daerah Dr M Yunus Bengkulu ditemukan klien dengan end stage renal disease yang menjalani terapi hemodialisa pada tahun 2015 sejumlah 930 klien sedangkan pada tahun 2016 klien yang menjalani terapi hemodialisa sejumlah 1102 klien hal ini menunjukan ada peningkatan klien dengan end stage renal disease yang menjalani terapi hemodialisa dari tahun ketahun. Sedangkan survey yang dilakukan peneliti pada bulan April 2017 di Unit Hemodialisa Rumah Sakit Umum Daerah Dr M Yunus Bengkulu di dapatkan hasil adanya penambahan berat badan > 5,7 $\%$ diantara dua waktu hemodialisa yang berjumlah 22 klien dimana hal ini menjadi indikasi dan manifestasi klinis serta indikator dimana masih adanya klien yang tidak 
patuh terhadap pembatasan asupan cairan. Informasi yang diberikan klien dan keluarga yang menjalani terapi hemodialisa ada beberapa faktor yang menjadi penyebab ketidakpatuhan klien dalam pembatasan asupan cairan diantaranya adalah kurangnya dukungan dari keluarga, tingkat pendidikan klien yang berbeda sehingga sulit untuk memahami semua informasi dan pengetahuan yang diberikan terkait cara-cara untuk meningkatkan kepatuhan dalam pembatasan asupan cairan yang dapat berdampak buruk terhadap kondisi klien itu sendiri, serta usia klien yang berbeda yang menjalani terapi hemodialisa sehingga menimbulkan tingkat kesadaran yang rendah terhadap kepatuhan pembatasan asupan cairan. Maka dari beberapa penjelasan diatas peneliti ingin mengetahui hubungan dukungan keluarga, tingkat pendidikan dan usia dengan kepatuhan dalam pembatasan asupan cairan pada klien end stage renal disease yang menjalani terapi hemodialisa di RSUD Dr M Yunus Bengkulu.

\section{METODE PENELITIAN}

Penelitian ini adalah penelitian kuantitatif dengan jenis penelitian observasional menggunakan desain cross sectional dimana digunakan untuk meneliti hubungan dukungan keluarga, tingkat pendidikan dan usia dengan kepatuhan dalam pembatasan asupan cairan pada klien end stage renal disease yang menjalani terapi hemodialisa di RSUD Dr M Yunus Bengkulu. Penelitian ini dilaksanakan bulan Juli 2019 di ruangan Hemodialisa RSUD Dr M Yunus Bengkulu.

Populasi dalam penelitian ini adalah semua klien end stage renal disease yang menjalani terapi hemodialisa di Rumah Sakit Umum Daerah Dr M Yunus Bengkulu dimana populasi dalam penelitian adalah klien end stage renal disease yang secara rutin minimal dua kali dalam seminggu menjalani terapi hemodialisa di Rumah Sakit Umum Daerah Dr M Yunus Bengkulu.

Tehnik pengambilan sampel dengan tehnik non probability sampling yaitu dengan consecutive sampling. Sampel dalam penelitian ini didapatkan sampel berjumlah 108 yang memenuhi kriteria inklusi. Dimana kriteria inklusi dalam penelitian ini adalah klien end stage renal disease yang menjalani terapi hemodialisa yang bersedia menjadi responden, klien end stage renal disease yang menjalani terapi hemodialisa dalam tingkat kesadaran penuh (compos mentis), klien end stage renal disease yang menjalani terapi hemodialisa yang mampu membaca, menulis, klien end stage renal disease yang menjalani terapi hemodialisa tidak mengalami gangguan pada sistem pengelihatan dan pendengaran. Sedangkan kriteria eksklusi adalah klien end stage renal disease menjalani terapi hemodialisa yang tidak kooperatif, klien end stage renal disease menjalani terapi hemodialisa yang harus disegerakan (cito), klien end stage renal disease menjalani terapi hemodialisa yang drop out atau mengundurkan diri, klien end stage renal disease menjalani terapi hemodialisa yang mengalami gangguan jiwa.

Prosedur pengumpulan data pada penelitian ini meliputi berbagai tahapan mulai dari prosedur administratif dengan cara mendapatkan surat keterangan lolos kaji etik serta mendapatkan perijinan untuk penelitian di RSUD Dr M Yunus Bengkulu. Prosedur teknis yang dilakukan dalam penelitian ini dengan cara meminta izin kepada penganggung jawab ruangan hemodialisa dalam hal ini kepala ruangan dan mensosialisasikan maksud dan tujuan penelitian kepada tim keperawatan ruangan hemodialisa. Langkah selanjutnya peneliti melakukan seleksi terhadap calon responden dengan berpedoman kepada kriteria inklusi, meminta kesediaan responden untuk menjadi sampel dengan terlebih dahulu menjelaskan maksud dan tujuan penelitian dan menandatangani lembar informed concent. 
Pelaksanaan dalam penelitian ini berlanjut ke tahapan menanyakan berat badan klien setelah melaksanakan terapi hemodialisa periode pertama. Kemudian peneliti melanjutkan penelitian pada periode hemodialisa selanjutnya dengan cara bertanya berat badan sebelum hemodialisa periode tersebut untuk mengetahui tingkat kepatuhan responden dalam melakukan pembatasan asupan cairan. Dilanjutkan dengan membagikan kuisioner yang akan diisi oleh responden terkait tentang tingkat pendidikan, usia dan dukungan keluarga terhadap kepatuhan dalam pembatasan asupan cairan klien end stage renal disease yang menjalani terapi hemodialisa di Rumah Sakit pada saat kunjungan melakukan terapi hemodialisa. Responden diposisikan senyaman mungkin bisa dengan baring atau duduk diatas tempat tidur sesuai dengan keinginan klien.

Hasil data dari penelitian ini dilakukan dengan memeriksa kembali data responden yang telah terkumpul. Kemudian dilakukan analisis data yang digunakan adalah analisis univariat dan bivariat. Analisis univariat dalam penelitian ini dilakukan untuk mengetahui karakteristik responden end stage renal disease yang menjalani terapi hemodialisa dimana data akan disajikan dalam bentuk tabel distribusi frekuensi. Sedangkan analisis bivariat dalam penelitian ini dilakukan untuk mengetahui hubungan dukungan keluarga, tingkat pendidikan dan usia terhada kepatuhan dalam pembatasan asupan cairan pada klien end stage renal disease yang menjalani terapi hemodialisa Di RSUD Dr M Yunus Bengkulu, yang diuji dengan menggunakan uji Chi-Square atau Khi-Kuadrat.

\section{HASIL PENELITIAN Analisi Univariat}

Tabel. 1

Distribusi Responden Berdasarkan Kepatuhan dalam Pembatasan Asupan Cairan, Dukungan Keluarga, Tingkat Pendidikan dan Jenis Kelamin, Klien End Stage Renal Disease yang Menjalani Terapi Hemodialisa

\begin{tabular}{lcc}
\hline Karakteritik responden & N & Persentase $(\%)$ \\
\hline Kepatuhan & & \\
Tidak Patuh & 12 & 11,1 \\
Patuh & 96 & 88,9 \\
Total & 108 & 100 \\
Dukungan Keluarga & & \\
Kurang Baik & 22 & 20,4 \\
Baik & 86 & 79,6 \\
Total & 108 & 100 \\
Pendidikan & & \\
Rendah & 42 & 38,9 \\
Tinggi & 66 & 61,1 \\
Total & 108 & 100 \\
Usia & & \\
Dewasa & 28 & 25,9 \\
Lansia & 80 & 74,1 \\
Total & 108 & 100 \\
\hline
\end{tabular}

Berdasarkan tabel 1 menunjukan bahwa kepatuhan dalam pembatasan asupan cairan pada klien end stage renal disease dominan patuh terhadap pembatasan asupan cairan di mana dari 108 klien yang patuh ada 96 (88.9 \%) responden dan yang tidak 
patuh ada $12(11.1 \%)$ responden. Dukungan Keluarga didapatkan bahwa dari 108 responden sebagian besar memiliki dukungan keluarga baik yaitu 86 (79.6\%) yang kurang baik ada $22(20.4) \%$ ) responden. Tingkat pendidikan didapatkan bahwa dari 108 responden sebagian besar memiliki tingkat pendidikan tinggi yaitu $66(61.1 \%)$ yang berpendidikan rendah ada $42(38.9 \%)$ responden. Sementara usia didapatkan bahwa dari 108 responden sebagian besar responden berusia lansia yaitu 80 (74.1\%) yang memiliki usia dewasa ada $28(25.9 \%)$ responden.

\section{Analisis Bivariat}

Tabel. 2

Distribusi Responden Menurut Dukungan Keluarga dan Kepatuhan dalam Pembatasan Asupan Cairan

\begin{tabular}{|c|c|c|c|c|c|c|c|}
\hline \multirow{3}{*}{$\begin{array}{c}\text { Dukungan } \\
\text { Keluarga }\end{array}$} & \multicolumn{4}{|c|}{ Kepatuhan Pembatasan Cairan } & \multicolumn{2}{|c|}{ Total } & \multirow[t]{3}{*}{ P Value } \\
\hline & \multicolumn{2}{|c|}{ Tidak Patuh } & \multicolumn{2}{|c|}{ Patuh } & & & \\
\hline & $\mathrm{N}$ & $\%$ & $\mathrm{~N}$ & $\%$ & $\mathrm{~N}$ & $\%$ & \\
\hline Kurang Baik & 12 & 54,5 & 10 & 45,5 & 22 & 100 & 0,000 \\
\hline \multirow[t]{2}{*}{ Baik } & 0 & 0 & 86 & 100 & 86 & 100 & \\
\hline & 12 & 11,1 & 96 & 88,9 & 108 & 100 & \\
\hline
\end{tabular}

Berdasarkan tabel 2 hasil analisis hubungan antara dukungan keluarga dengan kepatuhan dalam pembatasan asupan cairan diperoleh bahwa ada sebanyak 10 (45,5\%) klien yang dukungan keluarga kurang baik yang patuh dalam pembatasan asupan cairan. Sedangkan diantara klien yang memiliki dukungan keluarga yang baik ada 86 $(100 \%)$ yang patuh dalam pembatasan asupan cairan. Hasil uji statistik diperoleh nilai $\mathrm{p}$ $=0,000$ maka dapat disimpulkan ada hubungan dukungan keluarga terhadap kepatuhan dalam pembatasan asupan cairan.

Tabel. 3

Distribusi Responden Menurut Tingkat Pendidikan dan Kepatuhan dalam Pembatasan Asupan Cairan

\begin{tabular}{cccccccc}
\hline Tingkat & \multicolumn{3}{c}{ Kepatuhan Pembatasan Cairan } & & \multicolumn{2}{c}{ Total } & \multirow{2}{*}{ P Value } \\
\cline { 2 - 5 } Pendidikan & \multicolumn{2}{c}{ Tidak Patuh } & \multicolumn{2}{c}{ Patuh } & & & \\
& $\mathrm{N}$ & $\%$ & $\mathrm{~N}$ & $\%$ & $\mathrm{~N}$ & $\%$ & \\
\hline Rendah & 4 & 9,5 & 38 & 90,5 & 42 & 100 & \\
Tinggi & 8 & 12,1 & 58 & 87,9 & 66 & 100 & 0,762 \\
& 12 & 11,1 & 96 & 88,9 & 108 & 100 & \\
\hline
\end{tabular}

Berdasarkan tabel 3 hasil analisis hubungan antara tingkat pendidikan dengan kepatuhan dalam pembatasan asupan cairan diperoleh bahwa ada sebanyak $38(90,5 \%)$ klien yang berpendidikan rendah yang patuh dalam pembatasan asupan cairan. Sedangkan diantara klien yang memiliki tingkat pendidikan tinggi ada 58 (87,9 \%) yang patuh dalam pembatasan asupan cairan. Berdasarkan hasil uji statistik diperoleh nilai $\mathrm{p}=0,762$ maka dapat ditarik kesimpulan tidak ada hubungan yang signifikan antara tingkat pendidikan terhadap kepatuhan dalam pembatasan asupan cairan. 
Tabel. 4

Distribusi Responden Menurut Kelompok Usia dan Kepatuhan dalam Pembatasan Asupan Cairan

\begin{tabular}{cccccccc}
\hline Kelompok Usia & \multicolumn{3}{c}{ Kepatuhan Pembatasan Cairan } & \multicolumn{2}{c}{ Total } & P Value \\
& \multicolumn{2}{c}{ Tidak Patuh } & \multicolumn{2}{c}{ Patuh } & & & \\
& $\mathrm{N}$ & $\%$ & $\mathrm{~N}$ & $\%$ & $\mathrm{~N}$ & $\%$ & \\
\hline Dewasa & 2 & 7,1 & 26 & 92,9 & 28 & 100 & 0,728 \\
Lansia & 10 & 12,5 & 70 & 87,5 & 80 & 100 & \\
& 12 & 11,1 & 96 & 88,9 & 108 & 100 & \\
\hline
\end{tabular}

Berdasarkan tabel 4 hasil analisis hubungan antara kelompok usia dengan kepatuhan dalam pembatasan asupan cairan diperoleh bahwa ada sebanyak $26(92,9 \%)$ klien yang kelompok usia dewasa yang patuh dalam pembatasan asupan cairan. Sedangkan klien yang masuk kedalam kelompok usia lansia ada $70(87,5 \%)$ yang patuh dalam pembatasan asupan cairan. Hasil uji statistik diperoleh nilai $\mathrm{p}=0,728$ maka dapat disimpulkan tidak ada hubungan kelompok usia terhadap kepatuhan dalam pembatasan asupan cairan.

\section{PEMBAHASAN}

\section{Analisis Univariat}

Berdasarkan tabel 1 menunjukan bahwa Kepatuhan dalam pembatasan asupan cairan pada klien end stage renal disease dominan patuh terhadap pembatasan asupan cairan. Dukungan Keluarga didapatkan bahwa dari 108 responden sebagian besar memiliki dukungan keluarga baik. Tingkat pendidikan didapatkan bahwa dari 108 responden sebagian besar memiliki tingkat pendidikan tinggi. Sementara usia didapatkan bahwa dari 108 responden sebagian besar responden berusia lansia yaitu.

Hasil distribusi responden untuk kepatuhan dalam pembatasan asupan cairan ini sejalan dengan penelitian yang dilakukan oleh Umayah (2016) dimana didapatkan hasil dari 31 responden sebagian besar klien patuh terhadap pembatasan asupan cairan pada klien gagal ginjal kronik.

Sementara untuk distribusi responden berdasarkan dukungan keluarga penelitian ini sejalan dengan penelitian Umayah (2016) dimana sebagian besar klien mendapatkan dukungan keluarga yang baik. Penelitian Ramelan dkk, (2013) mengatakan hal yang sama dimana sebagian besar responden mendapatkan dukungan keluarga yang baik.

Untuk hasil distribusi responden berdasarkan tingkat pendidikan hal ini tidak sejalan dengan penelitian yang dilakukan oleh Ramelan dkk, (2013) dimana sebagian besar responden dengan tingkat pendidikan menengah kebawah. Menurut peneliti klien yang mengalami end stage renal disease sebagian besar terjadi pada klien yang memiliki pendidikan tinggi dikarenakan semakin tinggi tingkat pendidikan seseorang tentunya akan semakin sibuk dengan rutinitasnya yang sebagian besar pekerjaanya hanya dilakukan diruangan yang dapat memicu terjadinya penurunan fungsi ginjal khususnya GFR total sehingga orang yang memiliki tingkat pendidikan lebih tinggi tentunya dapat lebih lebih berisiko mengalami kondisi end stage renal disease.

Untuk distribusi responden berdasarkan usia hal ini sejalan dengan penelitian Umayah (2016) dimana sebagian besar responden berusia lansia. Menurut peneliti klien yang menderita end stage renal disease yang berada pada usia lansia dimana telah terjadi penurunan fungsi ginjal secara terus menurun seiring dengan penambahan usia sehingga akan terjadi penurunan GFR sehingga lansia lebih beresiko mengalami end stage renal disease. 
Hal ini diperkuat oleh teori dimana Semakin bertambahnya usia fungsi ginjal juga semakin menurun, dimana setelah usia 40 tahun akan menyebabkan terjadinya penurunan laju filtrasi glomerulus secara progresif hingga umur 70 tahun yaitu kurang lebih 50 dari normalnya (Hanum dkk, 2015).

\section{Analisis Bivariat}

Berdasarkan tabel 2 didapatkan hasil analisis hubungan antara dukungan keluarga dengan kepatuhan dalam pembatasan asupan cairan diperoleh bahwa ada hubungan dukungan keluarga terhadap kepatuhan dalam pembatasan asupan cairan.

Hasil penelitian ini sejalan dengan hasil penelitian yang dilakukan oleh Sumigar dkk, (2015) yang mengatakan dukungan keluarga berhubungan dengan dengan kepatuhan diet pada klien end stage renal disease dengan nilai $p$ value $=0,001$. Selain itu hasil penelitian Kamaluddin dkk, (2009) mengatakan hal yang sama dimana perbedaan antara keterlibatan keluarga pada penderita patuh dengan yang tidak patuh dengan $p$ value $=0.000$ dimana diperoleh hasil ada pengaruh keterlibatan keluarga dengan kepatuhan klien dalam mengurangi asupan cairan. Dalam hal ini keterlibatan keluarga dapat diartikan sebagai suatu bentuk hubungan sosial yang bersifat menolong dengan melibatkan aspek perhatian, bantuan dan penilaian dari keluarga.

Dukungan keluarga merupakan suatu bentuk perhatian, dorongan yang didapatkan klien dari orang lain melalui hubungan interpersonal yang terdiri dari perhatian, emosional dan penilaian (Sumigar dkk, 2015). Dukungan keluarga yang baik sangat berpengaruh dalam menentukan keyakinan dan nilai kesehatan serta mempengaruhi proses penyembuhan lewat pemberian perhatian, rasa dicintai, dihargai dapat menjadi motivasi yang besar untuk patuh dalam menjalankan diet (Sumigar,dkk, 2015).

Selain itu keluarga juga merupakan faktor yang berpengaruh dalam menentukan program pengobatan, derajat dimana seseorang terisolasi dari pendampingan orang lain, isolasi sosial secara negatif berhubungan dengan kepatuhan (Kamaluddin dkk, 2009). Dukungan keluarga dalam hal ini memberikan motivasi, perhatian, mengingatkan untuk selalu melakukan pembatasan asupan cairan sesuai dengan anjuran tim medis. Dukungan keluarga juga mempunyai hubungan yang positif yang dapat mempengaruhi kesehatan individu dan kesejahteraannya atau dapat meningkatkan kreativitas individu dalam kemampuan penyesuaian yang adaptif terhadap stres dan rasa sakit yang dialami (Sari, 2009).

Teori lain mengatakan bahwa dukungan keluarga merupakan salah satu faktor yang mempengaruhi ketidakpatuhan. Keluarga dapat membantu menghilangkan godaan pada ketidakpatuhan dan keluarga seringkali dapat menjadi kelompok pendukung untuk mencapai kepatuhan (Rini, 2013).

Menurut peneliti dukungan keluarga merupakan hal yang sangat penting untuk menciptakan perilaku yang patuh terhadap pembatasan asupan cairan karena mendapatkan perhatian secara langsung dari keluarga, merasa selalu dicintai, dihargai sehingga akan menumbuhkan keyakinan dan motivasi untuk patuh terhadap proses penyembuhan dan perawatan yang sedang dijalani oleh klien.

Sementara berdasarkan tabel 3 hasil analisis hubungan antara tingkat pendidikan dengan kepatuhan dalam pembatasan asupan cairan diperoleh bahwa ada sebanyak 38 $(90,5 \%)$ klien yang berpendidikan rendah yang patuh dalam pembatasan asupan cairan. Sedangkan diantara klien yang memiliki tingkat pendidikan tinggi ada $58(87,9 \%)$ yang patuh dalam pembatasan asupan cairan. Berdasarkan hasil uji statistik diperoleh nilai $\mathrm{p}$ 
$=0,762$ maka dapat ditarik kesimpulan tidak ada hubungan yang signifikan antara tingkat pendidikan terhadap kepatuhan dalam pembatasan asupan cairan.

Hasil penelitian ini sejalan dengan hasil penelitian Hidayati (2012) yang mengatakan tidak ada hubungan yang signifikan antara pendidikan dengan penambahan berat badan diantara dua waktu hemodialisa atau ketidakpatuhan dalam pembatasan cairan pada klien end stage renal disease yang menjalani terapi hemodialisa.

Tingkat pendidikan tidak mempengaruhi perubahan perilaku, hal ini tergantung terhadap ketersediaan sumber informasi yang ada. Petugas kesehatan memiliki peranan yang sangat penting terhadap perubahan perilaku klien dengan memberikan informasi yang jelas kepada klien berupa penyuluhan kesehatan (Hidayati, 2012).

Penelitian lain juga mengatakan tidak ada hubungan yang signifikan antara tingkat pendidikan dengan kejadian penambahan berat badan diantara dua waktu hemodialisa atau kepatuhan dalam pembatasan asupan cairan pada klien End Stage Renal Disease yang menjalani terapi hemodialisa (Istanti, 2014).

Kondisi ini memperlihatkan bahwa kemampuan melakukan perawatan mandiri selama hemodialisa terutama pengelolaan terhadap pembatasan asupan cairan tidak hanya dipengaruhi oleh tingkat pendidikan akan tetapi dihasilkan dari interaksi pengetahuan, sikap dan tindakan klien dalam pengelolaan cairan dan diet yang diperoleh dari pengalaman sendiri atau sumber lainya.

Pendidikan merupakan upaya persuasi atau pembelajaran kepada masyarakat agar masyarakat atau inndividu mau melakukan tindakan-tindakan (praktik) untuk memelihara (mengatasi masalah-masalah yang dihadapi dalam kehidupan), dan meningkatkan kesehatannya. Perilaku positif yang menjadi dasar pengertian (pemahaman) dan perilaku dalam diri seorang individu. Hasil atau perubahan perilaku dengan cara ini membutuhkan waktu lama, tetapi perubahan yang dicapai akan bersifat langgeng karena didasari oleh kesadaran mereka sendiri. Tingkat pendidikan individu memberikan kesempatan yang lebih banyak terhadap diterimanya pengetahuan baru termasuk informasi kesehatan (Sari, 2009).

Sehingga menurut peneliti tingkat pendidikan tidak terlalu berperan terhadap kepatuhan dalam pembatasan asupan cairan karena meskipun tingkat pendidikan yang tinggi tanpa di dukung oleh adanya pengetahuan atau pemberian informasi terkait tata cara atau standar operasional prosedur dari tindakan pembatasan asupan cairan secara terus menerus dan berkelanjutan serta didukung oleh pengalaman yang mencukupi tentang dampak dari ketidakpatuhan dalam pembatasan asupan cairan seperti munculnya kondisi peningkatan tekanan darah, sesak napas, edema, kelemahan, gangguan tidur, pruritus atau gatal-gatal maka kepatuhan terhadap pembatasan asupan cairan tersebut tidak akan dilakukan dengan baik dan optimal.

Hal ini diperkuat juga oleh teori yang diungkapkan oleh Ramelan dkk, 2013 bahwa faktor yang paling mempengaruhi terhadap peningkatan kepatuhan dalam pembatasan asupan cairan pada klien End Stage Renal Disease yang menjalani terapi hemodialisa yaitu faktor pengetahuan.

Sementara berdasarkan tabel 4 hasil analisis hubungan antara kelompok usia dengan kepatuhan dalam pembatasan asupan cairan diperoleh bahwa ada sebanyak 26 $(92,9 \%)$ klien yang kelompok usia dewasa yang patuh dalam pembatasan asupan cairan. Sedangkan klien yang masuk kedalam kelompok usia lansia ada $70(87,5 \%)$ yang patuh dalam pembatasan asupan cairan. Hasil uji statistik diperoleh nilai $\mathrm{p}=0,728$ maka dapat disimpulkan tidak ada hubsungan kelompok usia terhadap kepatuhan dalam pembatasan asupan cairan. 
Hal ini sejalan dengan penelitian Kamaluddin \& Rahayu (2009) tentang faktorfaktor yang mempengaruhi kepatuhan asupan cairan yang menjelaskan bahwa tidak ada pengaruh antara usia klien dengan kepatuhan dalam mengurangi asupan cairan. Sedangkan hasil penelitian lain mengatakan hal yang sama yaitu menurut Hidayati (2012) tidak ada hubungan yang signifikan antara usia dan penambahan berat badan diantara dua waktu hemodialisa atau kepatuhan dalam pembatasan asupan cairan.

Menurut peneliti usia yang lebih tua belum tentu akan lebih patuh terhadap pembatasan asupan cairan bila tidak ditunjang oleh pengetahuan dan informasi sebagai faktor sarana terjadinya perubahan prilaku dan kurangnya pengalaman yang pernah dialami klien terkait dengan pembatasan asupan cairan sehingga kepatuhan dalam pembatasan asupan cairan pada berbagai usia merupakan masalah yang sama. Seperti yang diungkapkan oleh Kamaluddin, Rahayu (2009) yang menunjukkan bahwa ketaatan terhadap aturan pengobatan pada anak-anak dan remaja merupakan persoalan yang sama dengan ketaatan pada klien dewasa.

\section{SIMPULAN}

Terdapat hubungan dukungan keluarga dengan kepatuhan dalam pembatasan asupan cairan pada klien end stage renal disease yang menjalani terapi hemodialisa di RSUD Dr M Yunus Bengkulu. Tidak terdapat hubungan tingkat pendidikan dengan kepatuhan dalam pembatasan asupan cairan pada klien end stage renal disease yang menjalani terapi hemodialisa di RSUD Dr M Yunus Bengkulu. Tidak terdapat hubungan usia dengan kepatuhan dalam pembatasan asupan cairan pada klien end stage renal disease yang menjalani terapi hemodialisa di RSUD Dr M Yunus Bengkulu.

Dukungan keluarga adalah hal sangat penting yang perlu diperhatikan sebagai salah satu faktor yang dapat menaikan serta meningkatkan kepatuhan dalam melakukan pembatasan asupan cairan klien yang mendapatkan tindakan hemodialisa, sehingga diharapkan dukungan keluarga dapat dimaksimalkan lagi pemberianya untuk menciptakan prilaku yang patuh sehingga mampu membuat klien sadar terhadap pembatasan asupan cairan dengan cara diinformasikan kepada pihak keluarga terutama melalui tatanan klinik hemodialisa yang senantiasa melayani klien end stage renal disease yang mendapatkan tindakan hemodialisa.

\section{SARAN}

Diharapkan penentu kebijakan di rumah sakit maupun layanan kesehatan baik milik pemerintahan maupun swasta terkhusus unit hemodialisa agar dapat memberikan informasi tentang pentingnya dukungan keluarga untuk meningkatkan kepatuhan dalam pembatasan asupan cairan pada klien end stage renal disease yang menjalani terapi hemodialisa. Untuk pengembang ilmu keperawatan diharapkan dapat menjadi sebuah pengetahuan terkhusus untuk mahasiswa keperawatan dalam memberikan pelayanan ketika melakukan praktik di unit hemodialisa serta dapat menjadi landasan teori sebagai salah satu indikator untuk meningkatkan kepatuhan klien dalam pembatasan asupan cairan yang menjalani terapi hemodialisa.

Sementara untuk pengembangan penelitian diharapkan dilakukan penelitian lebih lanjut dengan menambah variabel-variabel penelitian yang lain seperti pengetahuan, informasi, adekuasi, keyakinan, sikap lama menjalani terapi hemodialisa yang dapat menjadi faktor-faktor lain yang berhubungan dengan kepatuhan dalam pembatasan asupan cairan klien end stage renal disease yang menjalani terapi hemodialisa tentunya dengan jumlah sampel yang lebih banyak. 


\section{DAFTAR PUSTAKA}

Blacks, M. J. \& Hawk, H. J. (2014). Keperawatan Medikal Bedah: Manajemen Klinis untuk Hasil yang Diharapkan. (8 ed ). Jakarta: Salemba Medika

Hanum, R., Nurchayati, S., Hasneli, N. Y. (2015). Pengaruh Pendidikan Kesehatan Secara Individual tentang Pembatasan Asupan Cairan terhadap Pengetahuan tentang Pembatasan Cairan dan IDWG (Interdialytic Weight Gain) pada Klien Hemodialisis. Jom, 2(2)

Hidayati, S. (2012). Efektifitas Konseling Analisis Transaksional tentang Diet Cairan terhadap Penurunan Interdialytic Weight Gain (IDWG) Pasien Gagal Ginjal Kronis yang Menjalani Hemodialisa di Rumah Sakit Umum Daerah Kardinah. Jakarta: Tesis

Ismail., Hasanuddin., Burhanuddin, B. (2012). Hubungan Pendidikan, Pengetahuan dan Motivasi dengan Kepatuhan Diet pada Klien Gagal Ginjal Kronik di Rumah Sakit Umum Pusat Dr. Wahidin Sudirohusodo Makassar. Volume 1 Nomor 3Tahun 2012. ISSN: 2302-1721

Istanti, P. Y. (2014). Hubungan Antara Masukan Cairan dengan Interdialytic Weight Gains (IDWG) pada Klien Chronic Kidney Diseases di Unit Hemodialisis RS Pku Muhammadiyah Yogyakarta. Profesi,10

Kamaluddin, R. \& Rahayu, E. (2009). Analisis Faktor-Faktor yang Mempengaruhi Kepatuhan Asupan Cairan pada Klien Gagal Ginjal Kronik dengan Hemodialisis di RSUD Prof. Dr. Margono Soekarjo Purwokerto. Jurnal Keperawatan Soedirman (The Soedirman Journal of Nursing), 4(1)

Kugler. (2005). Nonadherence with Diet and Fluid Restrictions among Adults Having Hemodialysis. Journal of Nursing Scholarship, 37(1)

Padila. (2012). Buku Ajar Asuhan Keperawatan Medikal Bedah. Yogyakarta: Nuhamedika

Pernefri. (2012). 5th Report of Indonesian Renal Registry. (Online). http://www.pernefriinasn.org/Laporan/4th\%20Annual\%20Report\%20Of\%20IRR \%202011.pdf. Diakses 25 Januari 2018

Ramelan, I. M., Ismonah., Hendrajaya. (2013). Analisis Faktor-Faktor yang Mempengaruhi Kepatuhan Pembatasan Asupan Cairan pada Klien dengan Chronic Kidney Disease yang Menjalani Hemodialisa. Semarang. (online). http://ejournal.stikestelogorejo.ac.id/index.php/ilmukeperawatan/article/view/181. Diakses 1 Agustus 2019

Rini, S., Rahmalia, S., Dewi, P. (2013). Hubungan Antara Dukungan Keluarga terhadap Kepatuhan dalam Pembatasan Asupan Nutrisi dan Cairan pada Pasien Gagal Ginjal Kronik dengan Hemodialisa . Program Studi Ilmu Kesehatan Universitas Riau. Pekanbaru

Riskesdas. (2013). Badan Penelitian dan Pengembangan Kesehatan Kementerian kesehatan ri. Jakarta. (online). http://www.depkes.go.id/resources/download/general/Hasil\%20Riskesdas\%20201 3.pdf. Diakses 25 Januari 2018

Sari, K. L. (2009). Faktor-Faktor yang Berhubungan dengan Kepatuhan dalam Pembatasan Asupan Cairan pada Klien Gagal Ginjal Kronik yang Menjalani Terapi Hemodialisis di Ruang Hemodialisa Rsup Fatmawati Jakarta. Jakarta: Skripsi

Smeltzer, S. C., \& Bare, B. G. (2008). Brunner and Suddarth's Teksbook of Medikal Surgical Nursing. Philadelphia Williams dan Wilkins 
Sudoyo, A. W., Setiyohadi, B., Alwi, I., Simadibrata, M. K., Setiati, S. (2009). Buku Ajar Ilmu Penyakit Dalam Jilid II Edisi v. Jakarta: Pusat Penerbitan Ilmu Penyakit Dalam

Sumigar, G., Rompas, S., Pondaag, L. (2015). Hubungan Dukungan Keluarga dengan Kepatuhan Diet pada Klien Gagal Ginjal Kronik di Irina C2 dan C4 Rsup Prof. Dr. r. d. Kandou Manado. Ejournal Keperawatan (e-Kep), 3(1)

Umayah, E. (2016). Hubungan Tingkat Pendidikan, Pengetahuan, dan Dukungan Keluarga dengan Kepatuhan dalam Pembatasan Asupan Cairan pada Pasien Gagal Ginjal Kronik (GGK) yang Menjalani Hemodialisa Rawat Jalan di RSUD Kabupaten Sukoharjo. Surakarta. Skripsi

Wahyudi, H., \& Fitri, M. H. (2012). Kepatuhan Diet dengan Berat Badan Pre Hemodialisis pada Klien Regular di Ruang Hemodialisa RSUD Nganjuk 